\title{
Analysis of the Realization Mechanism of the Regional Low-Carbon Innovation System Based on the Technological Forecasting
}

\author{
Liping Wang* \\ School of Economics \\ Shandong University of Finance and Economics \\ Jinan, P.R.China
}

\begin{abstract}
The regional low-carbon innovation system is in accordance with the basic requirements of the sustainable development, and is an effective way to save the energy, reduce the emission of the carbon dioxide and realize the low-carbon economy. This paper analyzes the characteristics of the regional low-carbon innovation system and the technological forecasting studies the role of the technological forecasting in the regional low-carbon innovation system and puts forward the realization mechanism of the regional low-carbon innovation system based on the technological forecasting. The technological forecasting could guide the regional low-carbon innovation activities and is helpful in integrating the innovation resources, constructing the regional low-carbon innovation social network, and providing early warning of the problems of the low-carbon innovation. To establish the low-carbon innovation system, the government should implement the key technique strategy, construct the incentive mechanism, optimize the supporting environment and lay a good public foundation for the low-carbon innovation.
\end{abstract}

Keywords-technological forecasting; regional; innovation system; low carbon

\section{INTRODUCTION}

With the development of society, the world economy has shown obvious characteristics of regionalization. The regional low ${ }^{-}$carbon innovation system is in accordance with the basic requirement of the sustainable development, and is an effective way to save the energy, reduce the emission of the carbon dioxide and realize the low-carbon economy. The technological forecasting is not only the preliminary prospect of future technology, but also the systematic prediction of the economy, society and science. The sustainable development of the technological forecasting makes it an important basis for constructing the regional innovation system, and the technological forecasting could provide an effective way to solve the problems encountered in the process of constructing the low-carbon innovation system.

\section{CHARACTERISTICS OF THE REGIONAL INNOVATION SYSTEM}

The regional innovation system is an organization system which is composed of the production enterprises, universities, scientific research institutions, governments and intermediary

This paper received financial support from the Natural Science Foundation of Shandong Province (ZR2010GM0113). institutions which take part in the research and development of the new technology within a region [1]. The regional lowcarbon innovation system aims at developing the low-carbon economy, and it is a network system of cooperative innovation which is composed of the enterprises, universities and governments that participate in the regional low-carbon technical innovation activities. This system is regional, lowcarbon, innovative and pluralistic [2].

\section{A. Regionalization}

The regional low-carbon innovation system exists in some special areas. This system consists of the enterprises, universities, etc. which belong to the same region geographically. These units could work and support each other to promote the creation, transfer and dissemination of the lowcarbon technologies and products. The regional low-carbon innovation system is an important part of the national lowcarbon innovation system and could be classified into different kinds of industrial low-carbon innovation system according to the industry categories. The industrial low-carbon innovation system includes the enterprise low-carbon innovation system (see Fig. 1).

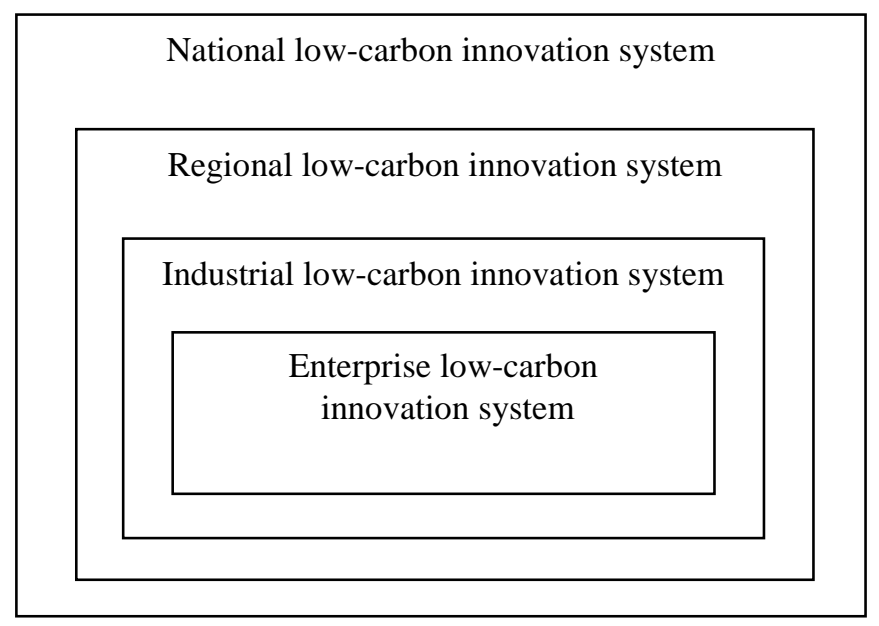

Fig. 1. The position of the regional low-carbon innovation system 


\section{B. Low carbon}

The regional low-carbon innovation system aims at developing the regional low-carbon economy, increasing the low-carbon technique level and pushing forward the innovation efficiency of the low-carbon system. At present, the government has realized that developing the low-carbon economy is the final way to solve the contradiction between the economic growth and the natural environment [3]. To establish a resource-saving and environment-friendly society, China must transfer from the traditional extensive economic growth mode with high input, high consumption and high pollution to the intensive low-carbon economic growth mode marked by low energy consumption and low emissions. Only by transforming to the innovation mode of low-carbon economy can we promote the sustainable development of the regional innovation system.

\section{Innovativeness}

The regional low-carbon innovation system is an innovative system which is formed by some regional innovation subjects through coordination and cooperation in a certain innovation environment [4]. The innovation units of the regional lowcarbon innovation system include the production enterprises, universities, research institutions, local governments and agencies. They could realize the innovation function through the interactions of the information and techniques and then influence the regional economic development [5].

\section{Multiplicity}

The low-carbon technical innovation activities are pluralistic because each region has its own technical foundation, natural environment, resource endowment, social culture and economic development characteristics. Each region is different in the starting point, content and development path of the lowcarbon technology innovation activities and finally, each region has a different level of the low-carbon innovation system, which leads to the unbalanced development of the regional low-carbon economy.

\section{CONNOTATION OF THE TECHNOLOGICAL FORECASTING}

Technological forecasting is the systematic research of the development of the science, technique, economy and society in the future, which aims at identifying the strategic areas of research and selecting the common techniques that have the maximum contribution to the economy and society. The technological forecasting has the following characteristics:

\section{A. Prospective}

On the one hand, the technological forecasting concerns the promotion of the future technology, makes efforts to popularizing the existing techniques to more fields, and this could improve the industrial structure and enhance the technological content of enterprises. On the other hand, the technological forecasting could push forward the development of the technology. It could provide the basis for the research and development of the new technologies through observing the current social system and judging the main demands of the society and the loopholes of the techniques.

\section{B. Systematicness}

The technological forecasting could be divided into the expert subsystem, the key technique subsystem, the policy information subsystem, the forecasting method subsystem and the management and maintenance subsystem. The expert subsystem is the core, which is mainly used to manage the personal data of the experts participating in the technological forecasting. The management and maintenance subsystem is the key. It controls the coordination, updating and maintenance of the sub-modules, and ensures the security of the system information. The policy information subsystem provides policy information support for the experts to make the final decisions, updates the latest technological policies, industrial policies, sustainable development policies in time, so that the experts' decisions are in line with the latest policy direction. The forecasting method subsystem provides the professional technological forecasting method. At present, the relatively mature methods include the Delphi method, the expert meeting method and the policy analysis method.

\section{Dynamics}

The technological forecasting system is not immutable, and it has two kinds of changes: the change of internal factors and the change of external form. The internal changes of the technological forecasting system include the internal changes of each subsystem, such as the change of the research direction of the experts, the policies changes, the updating of key technologies, the innovation of the forecasting methods, etc. The external change of the technological forecasting system refers to the change of the sub-modules of the system, and this leads to the reduction or increase of the existing system submodules.

\section{Open}

The technological forecasting system exchanges information with the outside world, adjusts the research direction in time with the social development, collects information of the technology, keeps up with the latest economic trend, and puts the information beneficial to the technological forecasting into the corresponding system submodule. At the same time, experts of different research directions are invited to participate in the research projects to ensure the high quality of the technological forecasting research. In addition, the openness of technological forecasting could help the public supervise the process of technological forecasting.

\section{E. Sustainability}

On the one hand, the goal of technological forecasting is to ensure the sustainable development of society. The development of the economy should take the environmental protection as the premise, promote the transition of the industry to the technology-intensive type through popularizing the new techniques, reduce the waste of resources, maximize the industrial benefit, and promote the sustainable development of society [6]. On the other hand, technological forecasting itself is also in a process of sustainable development. The techniques develop very fast, and the technological forecasting should keep up with the development and application of science and 
technology in time, popularize the existing techniques to more fields, and actively develop new techniques that are in need.

\section{THE ROLE OF THE TECHNOLOGICAL FORECASTING IN THE REGIONAL LOW-CARBON INNOVATION SYSTEM}

With the rapid development of the economy, the extensive development mode makes the environment pollution more and more serious, resulting in the waste of a large number of nonrenewable resources. If the industrial development mode is not adjusted in time, human society will face a great threat. The low-carbon innovative development refers to the development which introduces the advanced technology and transfers from the extensive development mode to the technology-intensive mode. It is a kind of sustainable development which could increase the economic benefits without damaging the environment. As an important adjustment mechanism of the regional low-carbon innovation system, the technological forecasting could guide all kinds of regional resources to the field of new technology and promote the development of the high technology industries. The roles of the technological forecasting in the regional low-carbon innovation system are as follows:

\section{A. Guiding the Regional Low-carbon Innovation Activities}

It is difficult for a region to realize low-carbon innovation. The small and medium-sized enterprises with limited resources and funds do not have the ability to engage in the research and development and need financial support from the government. Even if the innovation subject has the ability to continuously engage in the $R \& D$, the $R \& D$ achievement can only have influence in a limited area. As a strategic tool of science and technology management, the technological forecasting could explore the competitive advantage of the resources in the region, master the policies and regulations conducive to the development of the low-carbon technological innovation in the region through the policy information subsystem, understand the current situation of the low-carbon innovation technology development, clarify the factors that affect the low-carbon innovation, and seek the unity of the economic benefit, social benefit and environmental benefit, applies the latest low-carbon techniques to the relevant fields, and provides strategic guidance for the regional governments to make policies to support the low-carbon technological innovation activities.

\section{B. Integrating the Regional Low-carbon Innovation Resources}

The implementation process of the technological forecasting includes collecting and integrating the regional low-carbon innovation resources, establishing groups to seek advice and suggestions on low-carbon innovation from the experts of different industrial backgrounds and putting forward the rationalization suggestions. In the process of regional lowcarbon innovation, the enterprises, universities and research institutions coordinate, all kinds of useful information is collected, and the government is given policy advice based on the technological forecasting. The technological forecasting integrates the low-carbon innovation resources, makes it efficient to use and distribute reasonably. The government integrates the limited resources and funds effectively and guides the market into the field of low-carbon innovation, and realizes the integration of resources in the region.

\section{Constructing the Regional Low-carbon Innovative Social Network}

The regional low-carbon innovation system is generally composed of the governments, enterprises, research institutions, universities and so on. Each unit provides information, technology, capital, talent and other elements respectively. This is not conducive to the development of the regional low-carbon technological innovation and the technological forecasting provides a platform for communicating with each other. The technological forecasting needs the participation of the whole society, including the governments, enterprises and so on, and pools all kinds of knowledge and resources. It connects the main bodies of the regional low-carbon innovation system directly or indirectly with some specific technological forecasting methods. In this process, the regional low-carbon innovation social network is constructed, and it saves the cost of low-carbon innovation.

\section{Providing Early Warning of the Problems of the Low- carbon Innovation}

The rapid development of science and technology has greatly facilitated the production, but it also induces many problems. Among them, the most concerned problem is the environmental problem. The gradual deterioration of the living environment has led to a series of health and safety problems that need to be solved urgently. The technological forecasting can collect all aspects of information about the low-carbon technological innovation, catch the existence of negative information in time, and track its causes and consequences, so as to take measures in time. The technological forecasting is conducive to adjusting the process of technological innovation.

\section{The Realization Mechanism of the Regional LOW-CARBON INNOVATION SYSTEM BASED ON THE TECHNOLOGICAL FORECASTING}

\section{A. Implementing the Regional Low-carbon Key Technology Strategy}

Today, with the increasing environmental pollution, the innovation and promotion of the low-carbon techniques are of great significance. The regional low-carbon key technology strategy mainly consists of two aspects. Firstly, develop lowcarbon products. The firms should use renewable material resources; reduce the use of limited resources. The products should meet the quality requirements, do not cause environmental pollution and can be recycled. Secondly, innovate the low-carbon production process. The firms should use clean energy such as the solar energy instead of the pollution energy such as the coal to reduce the pollutant emission and strengthen the treatment of the pollutants in the manufacturing process. The choice of the key techniques should meet the social needs. 


\section{B. Constructing the regional low-carbon innovation Incentive Mechanism}

Firstly, improve regional low-carbon innovation policies. On the one hand, we should carry out new policies to support the low-carbon technological innovation. On the other hand, we should revise the old policies that are not in line with economic development. Secondly, establish the regional lowcarbon innovation incentive mechanism. The incentive mechanism is a powerful driving force for the regional lowcarbon innovation. If the government does not take incentive measures, the firms don't have the motivation to develop lowcarbon techniques [6]. Thirdly, strengthen the management of the regional low-carbon innovation environment. The traditional cost-benefit analysis method does not consider the environmental benefit. Through the supervision of the lowcarbon innovation environment, the low-carbon environmental benefit is added to the traditional cost-benefit analysis, and the determination of the production cost and benefit is more scientific and effective. At the same time, the calculation results can provide the basis for the government to reward and punish the firms.

\section{Optimizing the Regional Low-carbon Innovation Supporting Environment}

Firstly, support the regional low-carbon innovation financially. The government guides the financial support system with enterprise investment as the main and social investment as the auxiliary. The government should strengthen the low-carbon development consciousness, increase the lowcarbon innovation financial investment, establish the lowcarbon innovation fund and provide the guarantee for the regional low-carbon innovation development. Secondly, train the regional low-carbon innovation talents. The universities should strengthen the low-carbon technology education, guide the college students to explore the low-carbon areas, and carry out the low-carbon technique training for the workers. Thirdly, extend the regional low-carbon market. Relax the low-carbon market entrance conditions, encourage the enterprises to develop the low-carbon products, expand the sales channels of the low-carbon products, and ensure the firms of the lowcarbon techniques could have profits [7].

\section{Laying Good Public Foundation for the Regional Low- carbon Innovation}

The regional low-carbon innovation is not only related to the interests of the governments, research institutions, colleges and universities and other departments but also closely related to the interests of the public. The technological forecasting should be guided by the social demand, which originates from the public demand. The technological forecasting needs the public to participate in the process actively. Thus, the questionnaire survey should be conducted among the public and the masses should be invited to take part in the seminar of the regional low-carbon innovation system and so on. In addition, low-carbon innovation achievements need to be further popularized among the public [8]. The achievements of the regional low-carbon innovation should be displayed in stages and become a fixed exhibition project of popular science. This can expand the influence of the technological forecasting and regional low-carbon innovation, make more people have low-carbon consciousness, consolidate the public foundation of the regional low-carbon innovation, and promote the development of the regional low-carbon innovation system.

\section{CONCLUSION}

The regional low-carbon innovation system based on the technological forecasting is conducive to the establishment of the low-carbon industrial production mode and the development of the low-carbon economy. Based on the analyses of the characteristics of the regional low-carbon innovation system and the technological forecasting, this paper studies the important role of the technological forecasting within the low-carbon innovation system. The technological forecasting could give a good guide to the regional low-carbon innovation activities and is helpful to make full use of the innovation resources, building the regional low-carbon innovation social network, and giving early information of the problems that exist in the process of the low-carbon innovation. To establish the low-carbon innovation system, the government should implement the strategies of the key techniques, construct the incentive mechanism, optimize the supporting environment and lay a solid foundation for the low-carbon innovation activites among the public.

\section{REFERENCES}

[1] Y. Su, and J. Chen, "Introduction to regional innovation systems in East Asia,” Technological Forecasting \& Social Change, vol. 100, pp. 80-82, 2015.

[2] H. Gao, and X.C. Du, "Construction and coordination mechanism of the regional low-carbon innovation system,” Chinese Population. Resources and Environment, vol. 2, pp. 1-4, February 2016. (In Chinese)

[3] Y. Hang, J. Y. Zhao, X. Xi, and Y. H. Zhang, "Evolution of regional low-carbon innovation systems with sustainable development: An empirical study with big-data,” Journal of Cleaner Production, vol. 11, pp. 1545-1563, 2018.

[4] Z. X. Gan, X. Bai, and Y. W. Feng, "Cooperative development of the low-carbon Innovation in Beijing, Tianjin and Hebei based on the framework of the regional low carbon innovation system function," Environment Protection, vol. 8, pp. 57-60, August 2016. (In Chinese)

[5] Y. L. Xu, and F. Y. Meng, "Research on the technology foresight of promoting the transformation of scientific and technological achievements,” Scientific Management Research, vol. 5, pp. 42-45, May 2018. (In Chinese)

[6] Y. M. Wang, "The construction of ecological civilization and the foresight of new generation technology," Scientific Management Research, vol. 10, pp. 9-11, 26, October 2018. (In Chinese)

[7] B. Q. Fan, and L. J. Wang, "Analysis of China's manufacturing lowcarbon innovation system, its crisis inducement and formation mechanism,” Chinese Soft Science, vol. 12, pp. 51-60, December 2016. (In Chinese)

[8] M. Li, and Q. L. Liu, "Relationship between technology diffusion and resources distribution of industry-university-research synergy innovation system: based on comparison between domestic enterprises and foreign capital high-tech enterprises in China," Science and Technology Management Research, vol. 23, pp. 19-25, December 2018. (In Chinese) 